\title{
Rasayan Chikitsa an Overview
}

\section{Sathe Shivanjali Balaso*1, Parve Shirish ${ }^{2}$, Lokhande Smita ${ }^{3}$}

1. PG Scholar,

2. Professor and Head of the Department,

3. Reader,

Department of Kayachikista, Annasaheb Dange Ayurvedic Medical College, Ashta.

\section{*Corresponding Author: shivanjalisathe10@gmail.com}

\section{Abstract-}

Ayurveda means Science of Life. It deals with each and every aspect of life. Health in Ayurveda is conceived as union of sound body, mind, senses \& soul Maintenance and promotion of health and happiness is the first objective while next is to prevention of disease and cure of sickness .Ayurveda offers wonderful tools for better lifestyle. The knowledge of Dinacharya

,Rutucharya, Swasthavritta,,Rasayana gives us a guideline for promotion of health. Trayouppasthambha i.e.Aahar (Diet), Nidra (Sleep),Bramhacharya (Sexual behavior) influences on health.

Rasayanchikishta is one of the specialized branches of Ayurveda which deals with maintenance of health. According to Modalities three types of RasayanaAchar,Draya,Aahar rasayana plays effective and safe solution for various health problems like life style disorders, dengenerative conditions etc. There are many other medicines as well as body purifications has rejuvenator properties. Acharya Charaka widely narrated the effect of specific thoughtsbehavior-life style pattern (Achara rasayana) on health which helps to boost the immunity for prevention of various hfection.

The aim of this study to review the importance of Rasayana in promotion of health and prevention of disease. All the relevant material was compiled from various books. Research articles are also searched form various websites. All references were collected and finally conclusion was drawn.

Key word-Rasayana ,Dinacharya, Rutucharya, swasthavritta ,Achar rasayana

\section{Introduction}

Ayurveda does not merely believe in adding the no. of years to life but it advocate adding quality of life to each year. To fulfill this aim Ayurveda maintains two separate branches in Ashtang Ayurveda Rasayan and Vajikarna.Due to unbalanced life style it is necessary to provide optimum 
nourishment to the Dhatus by Rasayan chikishta.Because of which people are able to live life longer and healthier. The word Rasayan is made by two words-"Rasa"\& "Ayan" .Rasa means fluid or juice \& Ayan means pathway .Hence the meaning of Rasayan is path of juice i.e. obtaining augmentation of Rasa .This is method through which the rasa is maintained in the body .The properly and timely used of Rasayan drugs promotes youthfulness ,provide longevity, memory ,intelligence ,complexion ,body glow and best physical strength, health sense etc.

According to Ayurveda the substance which decreases ageing process, increase the longevity and mental as well as physical strength and which also destroys the disease process is called as Rasayan .For Vyadhiksamatva purpose Rasayan drugs are particularly used .Other measures are Shodhana and practicing th rules of Dinacharya,Sadvritta Rasayan.

\section{Need of study}

Today with changing lifestyle people are suffering from different disorders hence to treat these disorders we not only need to give medication but we need to follow the healthy lifestyle. For that we need to know the ill habits which cause the various disease and solution for that through healthy lifestyle.

\section{Aim and objectives}

- To review Rasayan mentioned in different Ayurvedic classical text.

- To study role of Rasayan in promotion of health and prevention of disease.

\section{Material and Method}

For the process of rejuvenation Ayurveda has described a unique therapy-Rasayan Therapy. Drugs described under Rasayan act on Agni, Dhatu and stoats level and help in formation of prashashta Dhatus maintaining a perfect equilibrium of all the Dosha and Dhatus.

\section{Types of Rasayan-}

\section{1) According to mode of Action or procedure-}

1. Kutipraveshika-It is indoor management. In this therapy person lives in specially formed Kuti for a longer period while taking various Rasayan herbs.

2. Vatatapik- It is outdoor management. In this therapy person does not bear stringent rules and can practiced in routine life.

\section{2) According to Modalities-}

1. Achar Rasayan-This type does not require internal administration of rejuvenating formula.' 'Achara', means discipline OR specific thoughts -behavior-life style pattern.

2. Ahar Rasayan-following the rules relating to eating i.e. Ashta Aharvidhivisheshaytana creates rejuvenation in peoples .Also following the Sattvika diet and life style ,speaking the truth, following social ethics and conducts are included under Rasayan.

3. Dravya Rasayan-It includes some herbs and food that are indeed beneficial for better functioning of body as well as brain. 
3 ) According to site of effect-

- Sharir Rasayan-This has specific effect of body .e.g. Guduchi, Shatavari.

- Manas Rasayan-This has effect on Mana. All medhya Rasayan are included in this category.

\section{4 ) According to preventive and curative aspect-}
1) Jaranashna Rasayan
2) Vyadhinashna Rasayan

\section{5) According to Varadhamana Rasayana-}

Vardhamana Rasayana

e.g. Pipali Rasayan ,Bhallataka Rasayan

\section{6) According to achievable outcome-}

1) Naimitika Rasayan-is given to balance a specific cause which is causing a disease in the body .It hastens the recovery from prevailing disease .e.g .Triphala Rasayan, Dhatri Rasayan

2)Ajasrika Rasayan-is used to maintain good health and improve the quality of life through a healthy lifestyle ,diet OR exercise e.g. Milk ,ghee, honey, adopting the principles of proper sleep.

3) Kamya Rasayan-is used to fulfill a wish or desire.

1) Medhya Kamya-used for enhancing the memory.

2) Prana kamya-used for achieving best quality of prana.

3) Ayush kamya-used for increasing longevity.
4)Chakshya kamya-used for maintaining healthy eyes.

Drugs acts as Rasayan according to Dhatu-

Table no.1

\begin{tabular}{|l|l|}
\hline Dhatu & Drugs \\
\hline Rasa & $\begin{array}{l}\text { All types of mantha and manda } \\
\text { such as kharjura mantha and } \\
\text { lajjamantha }\end{array}$ \\
\hline Rakta & Loha,Tambra,Abhraka,Rouypa \\
\hline Mansa & Bala,Shatvri, Suvarna \\
\hline Meda & Vasa, Meda \\
\hline Ashti & $\begin{array}{l}\text { Pravala,Abha,Ajjashti,Kukkutandat } \\
\text { waka }\end{array}$ \\
\hline Majja & Vasa,Majja,Rouypya bhasma \\
\hline Shukra & $\begin{array}{l}\text { Dhudh,Kapikacchu,Bramhi,Mandu } \\
\text { kaparni }\end{array}$ \\
\hline
\end{tabular}

The main Ayurvedic texts used in this tudy are Charaka samhita, Shushruta amhita and available commentaries on theses .Material related to Rasayan concept and other relevant topics have been collected .We have also referred to the modern texts and searched various websites and reports to collect information.

\section{Single drugs and Bhasma as Rasayan-}

Suvarna, Loha bhasma, Amalki,Haritaki, Gudhuchi, Vacha, Jatamansi ,Bala ,Shilajit, Yashtimadhu

\section{Some preparations used as Rasayan-}

Chavanprasha, Bhallataka, Pipali ,Amalki ,Haritaki Rasayan

Pharmacological action of $s$ Rasayan drugs mentioned in charak samhita-

Table no.2 


\begin{tabular}{|l|l|}
\hline Amalki & $\begin{array}{l}\text { Rich in antioxidant, } \\
\text { strengthen the defense } \\
\text { mechanism against free } \\
\text { radicals }\end{array}$ \\
\hline Haritaki & $\begin{array}{l}\text { In Immune-modulations } \\
\text { studies,humoral immunity } \\
\text { was enhanced and cell } \\
\text { mediated immune response } \\
\text { was stimulated }\end{array}$ \\
\hline Gudhuchi & $\begin{array}{l}\text { Inhabits the lipid per } \\
\text { oxidation sans superoxide } \\
\text { and hydroxyl radicals in } \\
\text { vitro }\end{array}$ \\
\hline Vacha & $\begin{array}{l}\text { It reduces toxins } \\
\text { formations and induce } \\
\text { elimination of toxins from } \\
\text { body }\end{array}$ \\
\hline Shilajit & $\begin{array}{l}\text { Significantly increases the } \\
\text { level of antioxidants which } \\
\text { ultimately maintains } \\
\text { optimum health and delay } \\
\text { ageing }\end{array}$ \\
\hline Suvarna & $\begin{array}{l}\text { Produces humeral immune } \\
\text { response and evaluate } \\
\text { immunomodulatory } \\
\text { activities }\end{array}$ \\
\hline
\end{tabular}

\section{Mode of action-}

To getting adequate quality and quantity of Ahara rasa with its proper circulation through channels is the main concept of Rasayan which helps to improve digestion and metabolism as well as microcirculations, thus enabling the organisms to procure the best qualities of different Dhatus .Rasayan acts on 7 dhatus which further improves the oja i.e. immunity. This oja leads to immune leads to immune the body by nonspecific which are medicated by neutophils helped by monocytes and by specific which are medicated by B lymphocytes which acts against the virus ,bacteria etc. And by humeral which are medicated by $B$ lymphocytes become plasma cells and produces immunoglobin which destroys antigens. Majority of Rasayan drugs works on multiple area and helps in achievement of Vyadhikshamatva through its Dipana ,Pachana, Medhya and non specific immune booster properties.

\section{Discussion-}

Rasayan drugs acts inside the human body by modulating the neuro-endocrinoimmune system to keep away from disease, Rasayan therapy enhances the quality of Rasa,enriches it with nutrients so one can attains longevity ,memory, intelligence ,freedom from disorders, youthfulness ,excellence of luster ,complexion and voice ,optimum development of physique and sense organs, mastery over phonetics and brilliance Oja represent vitality, vigor and capacity to resist decay and disease. yadhikshamvta depends on the presence Oja. The deficiency of Ojas leads to degeneration of body .Rasayan acts as 'Immunomodulator of body' by acting on T-lymphocytes and B-lymphocytes.

\section{Conclusion and Result-}

Rasayan therapy means procedure of rejuvitalization and revitalization. Rasayan is used to improve Vyadhikshyamtva it may be helpful to promotes the health and prevention of disease .There are many drugs as well as body purification have rejuvenator properties .Life style code i.e. Achara Rasayan ,Dinnacharya, Rutucharya, Sadhvrita can be used for prevention of disease and improve quality of life. Vast research studies are needed so that can be used as preventive tool in future.

\section{Reference-}


1. Yadavji Trikamji Acharya,Commentary Ayurveda Dipika of Chakrapanidatta on Charak Samhita of Agnivesha,Chikista Stana. $8^{\text {th }}$ ed,Varanasi;Chowkhambha Sankrit Series,P.376

2. Ravi Datta Tripathi,Charak Samhita of Agnivesha,Chikista Stana. $1^{\text {st }}$ ed, Varanasi;Chowkhambha Sanskrit Series,2005.p.4,5,43.

3. kaviraj Dr.Ambikadautt Shastri, Sushruta Samhita of Sushruta,sutrastana; $1^{\text {st }}$ ed,Varanasi;Chowkhambha Sanskrit series,2005.p.43

4. 4.Talekar Manisha,Rasayana as a public Health Tool in Communicable Disease;A Review;Int.Jou.Of Ayu.Med,6(1),2015,page 1-7

5. Dandekar Pradnya D.,Role Rasayanchikishta in Promotion of
Health;Uni.Jou.of Ayu.\& Her.Med.,02(01),2014,Page 6-10.

6. Bagde

A.B.,Rasayanachikista;Antiagening Therapy

of Ayurveda;Int.Res.Jou.of Pharma, 4(4),2013,Page 64

7. Manoday Mohod.,Role of Rasayana in Promotion of health and Prevention of Disease-A Review;Shubhadra Int.Jou.Of Ayu.01(02),April 2017,Page 12-16

8. Mathew $S$ et al,"Antioxident activity of tinospora cordifolia and its usefulness in the amelioration of cyclophosphamide induced toxicity"- Amla cancer research centre,Kerala,India 1997

9. Prakash Chandra Gupta."Biological and pharmacological properties of Terminalia chebula retz.(Haritaki)an overview."International Journal of Pharmacy and Pharmaceutical Sciences.2012;4(3)
Rasayan Chikitsa an Overview

Sathe Shivanjali Balaso, Parve Shirish, Lokhande Smita

Ayurlog: National Journal of Research in Ayurved Science- 2018; (6)(6): 1-5 